\title{
Behavior of immunocastrated pigs
}

\section{Rita de Kássia Silva dos Santos ${ }^{1}$, Fabiana Ribeiro Caldara ${ }^{2}$, Marta Moi $^{3}$, Luan Sousa dos Santos ${ }^{4}$, Irenilza Alencar Nääs ${ }^{2}$, Luciana Foppa ${ }^{1}$, Rodrigo Garófallo Garcia ${ }^{2}$, Rusbel Raul Aspilcueta Borquis ${ }^{2}$}

\footnotetext{
${ }^{1}$ Universidade Federal da Grande Dourados, Programa de Pós-Graduação em Zootecnia, Dourados, MS, Brazil.

2 Universidade Federal da Grande Dourados, Faculdade de Ciências Agrárias, Dourados, MS, Brazil.

${ }^{3}$ Universidade Federal de Goiás, Programa de Pós-graduação em Zootecnia, Goiânia, GO, Brazil.

${ }^{4}$ Universidade Estadual Paulista "Júlio de Mesquita Filho", Faculdade de Ciências Agrárias e Veterinárias, Programa de Pós-graduação em Zootecnia, Jaboticabal, SP, Brazil.
}

\begin{abstract}
The objective of this study was to evaluate the behavior of immunocastrated male pigs compared with females and castrated males during the period before and after full immunization. A total of 30 animals were divided into three treatments, with ten animals in each (females, barrows, and immunocastrated males). The experiment was divided into three periods: 70 to 80 days of age (period 1), 81 to 110 days of age (period 2), and 111 to 140 days of age (period 3). The behavior of animals during these stages was evaluated. Immunocastrated males showed a higher rate of aggressive and sexual behavior during period 2, which decreased after the second vaccine dose. Both barrows and immunocastrated males presented high locomotion in period 1, reducing the frequency of this activity in period 3. All analyzed animals had a higher level of activities such as drinking, playing, and sexual behavior in period 1 than in the other periods, decreasing during the experiment. The remaining behavioral responses did not differ between the studied categories. Immunocastrated males had higher proportions of undesirable behaviors (aggressive and sexual) related to the surgically castrated males and females, and these were reduced after the second vaccine dose. Immunocastration is effective in the reduction of behaviors such as agonistic and sexual at the same levels observed in females and surgically castrated males. However, immunocastrated pigs are more subject to these undesirable behaviors before full immunization.
\end{abstract}

Key Words: immunocastration, sexual activity, sus scrofa, swine production, welfare

\section{Introduction}

Surgical castration has long been used as a single alternative to eliminate the taint of meat from male pigs, which is improper for consumers (Martins et al., 2013). Other indications for the castration procedure include the reduction of aggressive and sexual behavior and easeness in the management tasks during production (Thun et al., 2006). Studies have shown that surgical castration causes stress, acute and chronic pain, wound infections, and depression in weight gain (Prunier et al., 2006), making it a questionable and avoided procedure in some countries (Jaros et al., 2005). However, the animal welfare cannot be improved merely by omitting the orchiectomy since male pigs have high levels of testosterone that exerts substantial behavioral effects (Rydhmer et al., 2010).

Received March 1, 2016 and accepted July 31, 2016.

Corresponding author: fabianacaldara@ufgd.edu.br

http://dx.doi.org/10.1590/S1806-92902016000900006

Copyright (C) 2016 Sociedade Brasileira de Zootecnia. This is an Open Access article distributed under the terms of the Creative Commons Attribution License (http://creativecommons.org/licenses/by/4.0/), which permits unrestricted use, distribution, and reproduction in any medium, provided the original work is properly cited.
The testicular function can be inhibited by the active immunization of male pigs against gonadotropin-releasing hormone - GnRH (Baumgartner et al., 2010). Therefore, the immunocastration is considered a feasible alternative as it is a practice that does not cause acute pain to animals, reducing stress (Martins et al., 2013). The immunocastration vaccine induces the formation of antibodies against $\mathrm{GnRH}$, a neuropeptide that is released from the hypothalamus to stimulate the secretion of luteinizing hormone $(\mathrm{LH})$ and follicle-stimulating hormone (FSH), which in turn regulate the production of testicular steroids (Rydhmer et al., 2010). These antibodies bind to the endogenous GnRH, preventing the secretion of LH and FSH from the pituitary gland, reducing the secretion of testicular steroids (Weiler et al., 2013). It has been proved that the vaccine against $\mathrm{GnRH}$ reduces the concentration of testicular steroids, including androstenone and skatole, lessening the size of the reproductive organs and the quantity of sperm (Jaros et al., 2005; Einarsson et al.,, 2009; Batorek et al., 2012).

However, few studies have focused on the behavioral consequences and welfare aspects of immunization of male pigs (Prunier et al., 2006; Baumgartner et al., 2010), since the administration of the second dose of the vaccine makes 
them behave as hogs. Thus, the objective of this study was to evaluate the behavior of immunocastrated male pigs compared to females and surgically castrated pigs during the period before and after the full immunization.

\section{Material and Methods}

This investigation was carried out according to the guidelines established by the Ethical Committee on the Animal Use in Experimentation of the Universidade Federal da Grande Dourados (Brazil), under the case No 031/2013, by the ethical principles of animal experimentation, care, and use.

The experiment took place on a commercial farm in Dourados, Mato Grosso do Sul, Brazil (latitude 22¹6'30" S and longitude $\left.54^{\circ} 49^{\prime} 00^{\prime \prime} \mathrm{W}\right)$. The climate is considered as Cwa according to Köppen classification (humid mesothermal climate with hot summers and dry winters) with average annual temperature of $23.6^{\circ} \mathrm{C}$.

The pigs (Large White $\times$ Landrace) in the trial had their origin on a farm without breeding program, presenting medium genetic potential (Rostagno et al., 2011). A total of 30 piglets were selected from the nursery phase (70 days of age) with an average weight of $25.2 \pm 2.8 \mathrm{~kg}$. The animals were distributed in a completely randomized design of three treatments (T1: female, T2: surgically castrated males, and T3: immunocastrated males), each treatment housed in a single pen. Each treatment had ten pigs, but only five animals were randomly selected for the behavioral observation and each animal was considered as an experimental unit.

Males from the surgically castrated treatment were subjected to orchiectomy on the seventh day of age. The procedure was done without anesthetic, having both testicles removed after local disinfection, with one transversal incision of the scrotum with a scalpel, and cutting the spermatic cords. After this procedure, repellent and healing cream was applied to the incision wound.

The chosen piglets for immunocastration were vaccinated using two dosages of Vivax ${ }^{\circledR}$, which contains a modified form of $\mathrm{GnRH}$ protein conjugate in an aqueous adjuvant system. The first dosage $(2 \mathrm{~mL} / \mathrm{pig}$ injected subcutaneously just behind and below the base of the ear) was applied 60 days before slaughter (80 days of age) and the second dosage, 30 days before slaughter (110 days of age) (Figure 1).

All piglets were reared under the same experimental conditions, in a conventional swine housing $(20 \mathrm{~m} \times 8.0 \mathrm{~m})$, ceilings of $4.0 \mathrm{~m}$, east-west orientation, masonry walls, and clay tiles. The house consisted of concrete floor pens on the front area and a shallow pool in the rear area. The open sidewalls were $1.55 \mathrm{~m}$ high and had polypropylene curtains for environmental control. The pens had a herd density of $1.0 \mathrm{~m}^{2} / \mathrm{pig}$ and semi-automatic feeders and drinkers were available.

The study lasted 70 days including the phases of growing ( 70 to 110 days) and finishing (110 to 140 days). All pigs were fed the same diet (Table 1), using the nutritional recommendations by Rostagno et al. (2011) for hogs during growth and females during the finishing phase. Diets and water were given ad libitum during all the experimental period.

The study was subdivided into three periods: period 1 , 70 to 80 days of age (before the application of the first dose of GnRH protein conjugate on T3); period 2, 81 to 110 days of age (between the application of the first and the second dose of GnRH protein conjugate on T3); and

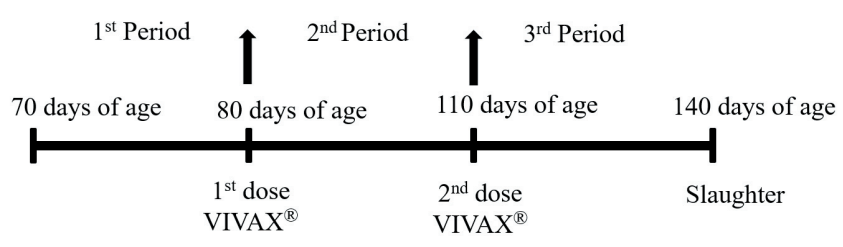

Figure 1 - Schema of the immunocastration protocol.

Table 1 - Centesimal diet composition and nutritional characteristics for growing and finishing pigs

\begin{tabular}{|c|c|c|}
\hline & $\begin{array}{c}\text { Growing* } \\
(\%)\end{array}$ & $\begin{array}{c}\text { Finishing } * * \\
(\%)\end{array}$ \\
\hline \multicolumn{3}{|l|}{ Ingredient } \\
\hline Soybean meal & 27.60 & 22.00 \\
\hline Corn & 68.50 & 75.30 \\
\hline Soybean oil & 0.50 & 0.13 \\
\hline Salt & 0.40 & 0.35 \\
\hline Dicalcium phosphate & 1.40 & 1.00 \\
\hline Limestone & 0.71 & 0.60 \\
\hline L-lysine & 0.40 & 0.25 \\
\hline DL-methionine & 0.10 & 0.05 \\
\hline L-threonine & 0.14 & 0.07 \\
\hline Vitamin/mineral mix & 0.25 & 0.25 \\
\hline \multicolumn{3}{|l|}{ Calculated nutritional values } \\
\hline Metabolizable energy (kcal/kg) & 3229.10 & 3236.59 \\
\hline Crude protein $(\%)$ & 18.4 & 16.2 \\
\hline Ether extract (\%) & 3.46 & 3.25 \\
\hline Crude fiber $(\%)$ & 2.65 & 2.47 \\
\hline Calcium (\%) & 0.70 & 0.55 \\
\hline Available phosphorus (\%) & 0.36 & 0.28 \\
\hline Sodium $(\%)$ & 0.18 & 0.16 \\
\hline Chlorine (\%) & 0.29 & 0.26 \\
\hline Lysine $(\%)$ & 1.44 & 0.89 \\
\hline Methionine (\%) & 0.35 & 0.28 \\
\hline Methionine + cystine (\%) & 0.62 & 0.52 \\
\hline Threonine $(\%)$ & 0.74 & 0.61 \\
\hline Tryptophan (\%) & 0.19 & 0.16 \\
\hline
\end{tabular}

* Recommendation for boars.

** Recommendation for females, according to Rostagno et al. (2011). 
period 3, 111 to 140 days of age (after the application of the second dose of GnRH protein conjugate on T3).

The pigs were identified by numbers in the lumbar area, made with a marker with ink stick. The behavioral assessment was carried out by direct observation, always made by the same observers. The number of animals and the activities performed during the three periods were noted on a worksheet. Each period consisted of three days of observation, distributed at the beginning, middle, and end of the period. The behavior was rated in 5-min intervals along $8 \mathrm{~h}$ every day ( 7.30 to $15.30 \mathrm{~h}$ ), according to Martin and Bateson (2007). Trained observers were placed inside the house in a way not to interfere with the behavior of pigs. The observers were rotated between treatments to avoid the effect of the observer. A table was built with the observations, characterizing the proportions of time spent in each behavior. Adjustments from previous research were made to describe the behavior of pigs (Campos et al., 2010; O'Connell et al., 2004; Pandorfi et al., 2006) (Table 2).

The behaviors standing still, lying awake, and sitting were considered the same at the time of statistical analysis and were identified as idleness. The sexual behavior, rooting other swine, and the agonistic behavior were seen as undesirable behaviors.

Statistical analysis was conducted using a nonparametric test for data repeated in time in a factorial model schema. The R software (R Core Team, 2015) was applied using the nparLD package with LD-F2-F2 function (Noguchi et al., 2012). In this study, 15 animals were stratified into three

Table 2 - Observed behaviors of castrated and immunocastrated males and females during growing and finishing

\begin{tabular}{ll}
\hline Behavior & \multicolumn{1}{c}{ Description } \\
\hline Sleeping & $\begin{array}{l}\text { Pig is lying, resting or sleeping on its lateral or } \\
\text { belly. } \\
\text { Pig is not doing activities. Pig is standing or } \\
\text { lying still. }\end{array}$ \\
Idleness & $\begin{array}{l}\text { Slow walking movement. } \\
\text { Commuting up }\end{array}$ \\
Pefecating/urinating & $\begin{array}{l}\text { Pooting the pen floor, lateral walls } \\
\text { and around the feeder. }\end{array}$ \\
Rooting the pen & $\begin{array}{l}\text { One pig rooting (any body part) or munching } \\
\text { (tail and ear) another pig. }\end{array}$ \\
Rooting other swine & Fighting, biting, or stretching other with the \\
teeth. Giving or receiving head-knocks or bites. & Head beating. \\
Agonistic behavior & Mounting or being mounted. \\
Pig is with the head in feeder or waiting for \\
food beside the feeder. \\
Eating
\end{tabular}

periods: period 1, period 2, and period 3 (Factor T1). In each stratification, the animals were assigned to treatments as follows: $\mathrm{A} 1=$ females, $\mathrm{A} 2=$ castrated males, and $\mathrm{A} 3=$ immunocastrated males (Factor A).

The scores of the observed data for each animal were recorded at 97-time points per day (Factor T2) to evaluate the effect of the time, treatment, and their interaction. Independent random vectors can describe the statistical model of this test. The null hypothesis of the main effect A, the main time $\mathrm{T} 1$ effect, and the interaction between $\mathrm{A}$ and T1 (AT1) are expressed regarding the marginal distribution functions:

$$
\begin{gathered}
H_{0}^{F}(A): \bar{F}_{1 .}=\cdots=\bar{F}_{a .} \\
H_{0}^{F}(T 1): \bar{F}_{.1}=\cdots=\bar{F}_{. t} \\
H_{0}^{F}(A T 1): F_{i s}=\bar{F}_{i .}-\bar{F}_{. s}+F_{. .} i=1, \ldots, a ; s=1, \ldots, t,
\end{gathered}
$$

$\bar{F}_{i .}=\frac{1}{t} \sum_{s=1}^{t} F_{i s}$ denotes an average distribution over time by group treatment $\mathrm{i} ; i=1, \ldots, a, \bar{F}_{s}=\frac{1}{a} \sum_{i=1}^{a} F_{i s}$ shows the average distribution in the treatment groups for the time point s; and $s=1, \ldots, t, e \bar{F}_{. .}=\frac{1}{a t} \sum_{i=1}^{a} \sum_{s=1}^{t} F_{i s}$ means the overall average and distribution.

To analyze the frequency of the behaviors, the average of the three days (291 points) was considered for all animals used in the treatment and each animal was regarded as an experimental unit. For this, the ANOVA was applied to compare the frequency of behaviors between treatments and periods.

\section{Results and Discussion}

There were differences between the treatments, periods, and their interactions (Table 3). Castrated males differed from females and immunocastrated males. By contrast, immunocastrated males and females did not differ. For the periods, there was a difference between periods 1 and 2, periods 1 and 3, but not between periods 2 and 3 .

There were differences between treatments for the following behaviors: rooting other swine (RO), agonistic behavior (AB), and sexual behavior (SB). Concerning the period, there were differences between sleeping ( $\mathrm{S}$ ), commuting up (C), rooting the pen (RP), and sexual behavior (SB) (Tables 4 and 5).

Regarding the behavioral frequency, the pigs, regardless of their condition in all periods, remained most of the time sleeping and the highest frequency of this behavior appeared in period 2 and 3 . In period 1, the pigs spent less time sleeping than in the other periods, probably due to 
the initial exploratory behavior. For confined animals, it is expected that they spend most of their time resting or sleeping (Broom and Fraser, 2010). A range of dynamic behaviors, mainly rooting, is considered as a good indicator of motivation and welfare, since in the wildlife, boars usually forage to find and examine sources of food.

The behaviors eating, idleness behavior, defecating and urinating, drinking, and playing did not differ in the present study (Table 5). On the other hand, immunocastrated animals, regardless of the evaluation period, had a higher frequency $(\mathrm{P}<0.05)$ of undesirable behavior (agonistic behavior, sexual behavior, and rooting other swine) than in the other treatments. Mounting, as a sexual characteristic, is part of the standard behavior of pigs. Hintze et al. (2013) found that a higher frequency of mounting (51.6\%) was related to sexual behavior, and it lasted between 1 and $10 \mathrm{~s}$. The authors suggest that sexual mounting causes more screaming by the mounted animal, indicating some distress and lack of welfare in the pigs. However, there was a gradual decrease in the incidence of sexual behavior during

Table 3 - Results of statistical analysis for the categories, periods, and their interactions by nonparametric factorial conducted by nparLD package: F2-LD-F2 function

\begin{tabular}{lcc}
\hline Situation & DF & P-value \\
\hline Treatments & 2 & $0.428542 \mathrm{e}-13$ \\
Periods & 2 & $0.999067 \mathrm{e}-14$ \\
Treatment $\times$ Period & 4 & $0.887495 \mathrm{e}-02$ \\
Female $\times$ Castrated & 1 & $0.386758 \mathrm{e}-13$ \\
Female $\times$ Immunocastrated & 1 & $0.492207 \mathrm{e}-01$ \\
Castrated $\times$ Immunocastrated & 1 & $0.456405 \mathrm{e}-09$ \\
P1 $\times$ P2 & 1 & 0.225524922 \\
P1 $\times$ P3 & 1 & $0.823273 \mathrm{e}-02$ \\
P2 $\times$ P3 & 1 & $0.454838 \mathrm{e}-01$ \\
\hline
\end{tabular}

DF - degrees of freedom.

P1 - Period 1 - prior to application of the 1 st dose of the immunocastration vaccine (70-80 days old); P2 - Period 2 - between the 1st and 2nd application of the vaccine dose (80-110 days old); P3 - Period 3 - after application of the 2nd dose of immunocastration vaccine (110-140 days old). the experimental periods, which can be justified by the fact that in period 1 , the immunocastrated condition had not received the first dose of vaccine, thus behaving as boars. After the second dose, the animals were fully immunized, with a decrease in testosterone production, which reduced the frequency of sexual behaviors. Although boars are more aggressive than castrated males, the expression of the undesirable behaviors, in the present study, can be related to the lack of environmental stimuli in the pen.

According to Cronin et al. (2003) and Rydhmer et al. (2006), boars express more sexual behavior than castrated pigs, regardless of the method of castration. The influence of the immunocastration on the testosterone concentration in male pigs was studied by Albrecht et al. (2012). The authors observed that immunocastrated males showed a similar level of testosterone as in boars. After the second dose of the vaccine, this level decreased, bringing a significant reduction in the agonistic and sexual behaviors, comparable to those levels of castrated pigs.

According to Andersen et al. (2000), the agonistic interactions are a means of defining the social hierarchy in the collective stall after mixing the groups. The observations made in this study corroborate Baumgartner et al. (2010), who observed an increased incidence of agonistic behaviors in immunocastrated pigs before the first vaccination, compared with the pigs castrated surgically, and decreased after receiving the second dose.

The more aggressiveness present in boars, as well as a higher incidence of sexual behavior, may suggest an insufficiency on the use of immunocastration, since it caused a decrease in the welfare status, and it may impair the meat and carcass quality. However, over the experimental period, there was a decline in the incidence of these behaviors, showing that the vaccine, besides preventing the occurrence of boar taint, is effective in reducing the unwanted behaviors. Thus, the most critical period to the

Table 4 - Frequency (\%) of the observed behaviors for treatments and periods

\begin{tabular}{|c|c|c|c|c|c|c|c|c|c|c|c|}
\hline & \multicolumn{11}{|c|}{ Behavior frequency (\%) } \\
\hline & $\mathrm{S}$ & I & $\mathrm{C}$ & $\mathrm{D} / \mathrm{U}$ & $\mathrm{RP}$ & RS & $\mathrm{AB}$ & $\mathrm{SB}$ & $\mathrm{E}$ & $\mathrm{D}$ & $\mathrm{P}$ \\
\hline \multicolumn{12}{|c|}{ Category } \\
\hline $\mathrm{T} 1$ & 54.60 & 18.75 & 3.00 & 0.44 & 9.30 & $1.40 \mathrm{~b}$ & $0.61 \mathrm{ab}$ & $0.10 \mathrm{~b}$ & 10.10 & 1.43 & 0.27 \\
\hline $\mathrm{T} 2$ & 54.01 & 18.43 & 2.90 & 0.45 & 10.36 & $1.70 \mathrm{~b}$ & $0.35 b$ & $0.30 \mathrm{ab}$ & 10.10 & 1.20 & 0.20 \\
\hline $\mathrm{T} 3$ & 55.98 & 17.94 & 2.97 & 0.45 & 9.25 & $3.80 \mathrm{a}$ & $1.47 \mathrm{a}$ & $0.82 \mathrm{a}$ & 10.40 & 0.42 & 0.30 \\
\hline \multicolumn{12}{|c|}{ Period } \\
\hline 1 & $47.20 \mathrm{~b}$ & 19.59 & $3.92 \mathrm{a}$ & 0.39 & $12.6 \mathrm{a}$ & 1.89 & 0.84 & $0.77 \mathrm{a}$ & 11.38 & 1.12 & 0.30 \\
\hline 2 & $54.80 \mathrm{a}$ & 16.81 & $2.68 \mathrm{~b}$ & 0.59 & $7.90 \mathrm{~b}$ & 3.25 & 0.98 & $0.30 \mathrm{ab}$ & 11.17 & 1.48 & 0.04 \\
\hline 3 & $55.90 \mathrm{a}$ & 18.28 & $2.33 b$ & 0.42 & $9.10 \mathrm{~b}$ & 1.80 & 0.61 & $0.16 \mathrm{~b}$ & 10.70 & 0.59 & 0.11 \\
\hline
\end{tabular}

S - sleeping; I - idleness; C - commuting up; D/U - defecating/urinating; RP - rooting the pen; RS - rooting other swine; AB - agonistic behavior; SB - sexual behavior; E - eating; $\mathrm{D}$ - drinking; P - playing.

T1 - females; T2 - surgically castrated males; T3 - immunocastrated males.

Period 1 - 70-80 days old; Period 2 - 80-110 days old; Period $3-110-140$ days old; $100 \%=8 \mathrm{~h}$.

Means followed by different letters in the column differ statistically by Tukey's test $(\mathrm{P}<0.05)$. 
Table 5 - Average frequency $(\min \pm \mathrm{SD})$ of the observed behaviors over a day of observation for all treatments

\begin{tabular}{lccc}
\hline \multirow{2}{*}{$\begin{array}{l}\text { Behavior } \\
(\text { min } \pm \text { SD })\end{array}$} & \multicolumn{3}{c}{ Treatment } \\
\cline { 2 - 4 } & $\mathrm{T} 1(\mathrm{n}=10)$ & $\mathrm{T} 2(\mathrm{n}=10)$ & $\mathrm{T} 3(\mathrm{n}=10)$ \\
\hline Sleeping & $248.55 \pm 3.09$ & $260.34 \pm 47.97$ & $261.56 \pm 31.61$ \\
Idleness & $91.45 \pm 10.01$ & $90.56 \pm 7.24$ & $77.12 \pm 12.30$ \\
Commuting up & $14.56 \pm 2.01$ & $14.39 \pm 7.58$ & $14.35 \pm 7.31$ \\
Defecating/urinating & $2.23 \pm 0.76$ & $2.56 \pm 0.18$ & $2.34 \pm 1.15$ \\
Rooting the pen & $52.23 \pm 4.62$ & $46.47 \pm 23.78$ & $44.71 \pm 6.20$ \\
Rooting other swine & $9.34 \mathrm{~b} \pm 0.88$ & $6.78 \mathrm{~b} \pm 1.01$ & $16.33 \mathrm{a} \pm 6.96$ \\
Agonistic behavior & $3.01 \mathrm{ab} \pm 1.66$ & $1.43 \mathrm{~b} \pm 0.19$ & $7.12 \mathrm{a} \pm 3.03$ \\
Sexual behavior & $0.23 \mathrm{~b} \pm 0.38$ & $1.45 \mathrm{ab} \pm 2.21$ & $4.01 \mathrm{a} \pm 3.05$ \\
Eating & $50.22 \pm 10.59$ & $48.01 \pm 10.39$ & $50.56 \pm 8.06$ \\
Drinking & $6.95 \pm 5.00$ & $7.01 \pm 2.18$ & $1.56 \pm 1.50$ \\
Playing & $1.23 \pm 1.34$ & $1.00 \pm 1.20$ & $0.34 \pm 0.33$ \\
\hline
\end{tabular}

T1 - females; T2 - surgically castrated males; T3 - immunocastrated males.

SD - standard deviation.

Means followed by different letters in the rows differ statistically by Tukey's test $(\mathrm{P}<0.05)$.

animal welfare would be the stage at which pigs begin to express their sexual characteristics when they received the second dose of vaccine, about 30 days before slaughter.

Velarde et al. (2008), Rydhmer et al. (2010), Baumgartner et al. (2010), and Andersson et al. (2012) assessed the effect of the immunocastration vaccine on the sexual and aggressive expression in the behavior of male pigs. The authors found that the behavior is modified after the second dose of the hormone vaccine with a reduction in sexual behavior compared with boars, at levels similar to surgically castrated pigs, and that these changes remained until slaughter. According to Claus et al. (2007), until the second dosage, the hypothalamic-pituitary-gonadal axis of vaccinated animals remains intact, even providing behavior of boars.

Fabrega et al. (2010) compared the performance and behavior of immunocastrated pigs and surgically castrated males and found a reduction of the activities of immunocastrated males at three days after the first dosage of the vaccine. The authors suggest that vaccination against $\mathrm{GnRH}$ might be associated with improvements in wellbeing during sexual maturity, as it reduces sexual activity and aggressive behavior, along with the productive benefits such as better growth rate and feed conversion.

The higher frequency of rooting other animals by immunocastrated animals suggests some association with sexual behavior. Behaviors such as sniffing or tweaking the genital area, riding accompanied by pelvic movements, and accepting to be mounted have been observed in pigs before puberty. Sex play may be related to the sexualization process and is more frequent among males than in females (Berry and Signoret, 1984).

All animal categories spent more time commuting up in period 1, reducing the frequency of the activity in subsequent periods. The occurrence of exploratory behaviors early on can be justified by the need to recognize the place, decreasing during the day due to housing habituation. Also, the fact that the animals were getting heavier over the periods may have contributed to their remaining more time in leisure. The frequency of locomotor activity has been identified as healthy and is used by young animals to establish social dominance (Donaldson et al., 2002).

Amongst the active behaviors, it was observed that the animals dedicated significant time to the exploration activity of the pen components (approximately 9.64\%), similar to the time spend on food. This fact indicates that even pigs reared on a pen with a nutritionally balanced diet do not lack the motivation to explore and search for food (Beattie and O'Connell, 2002; Studnitz et al., 2007).

\section{Conclusions}

Immunocastration is effective in the reduction of behaviors such as agonistic and sexual at the same levels observed in females and surgically castrated males. However, immunocastrated pigs are more subject to these undesirable behaviors before full immunization.

\section{Acknowledgments}

The authors would like to thank FUNDECT (Fundação de Apoio ao Desenvolvimento do Ensino, Ciência e Tecnologia do Estado de Mato Grosso do Sul) for funding this research.

\section{References}

Albrecht, A. K.; Beilageb, E. G.; Kanitzc, E.; Puppec, B.; Traulsena, I. M. and Krietera, J. 2012. Influence of immunisation against GnRF on agonistic and mounting behavior, serum testosterone concentration and body weight in male pigs compared with boars and barrows. Applied Animal Behavior Science 138:28-35.

Andersen, I. L; Andenaes, H.; Bøe K. E.; Jensen, P. and Bakken, M. 2000. The effects of weight asymmetry and resource distribution on aggression in groups of unacquainted pigs. Applied Animal Behavior Science 68:107-120.

Andersson, A.; Brunius, C.; Zamaratskaia, G. and Lundström, K. 2012. Early vaccination with Improvac ${ }^{\circledR}$ : effects on performance and behavior of male pigs. Animal 6:87-95.

Batorek, N.; Čandek-Potokar, M.; Bonneau, M. and Van Milge, J. 2012. Meta-analysis of the effect of immunocastration on production performance, reproductive organs and boar taint compounds in pigs. Animal 6:1330-1338.

Baumgartner, J.; Laister, S.; Koller, M.; Pfützner, A.; Grodzycki, A. M.; Andrews, S. and Schmoll, F. 2010. The behavior of male fattening pigs following either surgical castration or vaccination with GnRF vaccine. Applied Animal Behavior Science 124:28-34.

Beattie, V. E. and O'Connell, N. 2002. Relationship between rooting behaviour and foraging in growing pigs. Animal Welfare 11:295-303. 
Berry, M. and Signoret, J. P. 1984. Sex play and behavioural sexualization in the pig. Reproduction Nutrition Development 24:507-513.

Broom, D. M. and Fraser, A. F. 2010. Comportamento e bem-estar de animais domésticos. 4.ed. Manole, Barueri, São Paulo.

Campos, J.; Tinôco, A. I. F. F.; Silva, F. F.; Pupa, J. M. R. and Silva, I. J. O. 2010. Enriquecimento ambiental para leitões na fase de creche advindos de desmame aos 21 e 28 dias. Revista Brasileira de Ciências Agrárias 5:272-278.

Claus, R.; Lacorn, M.; Danowski, K.; Pearce, M. C. and Bauer, A. 2007. Short-term endocrine and metabolic reactions before and after second immunization against GnRH in boars. Vaccine 25:4689-4696.

Cronin, G. M.; Dunshea, F. R.; Butler, K. L.; McCauley, I.; Branett, J. L. and Hemswoeth, P. 2003. The effects of immune- and surgical-castration on the behavior and consequently growth of group- housed, male finisher pigs. Applied Animal Behavior Science 81:111-126.

Donaldson, T. M.; Newberry, R. C.; Spinka, M. and Cloutier, S. 2002. Effects of early play experience on play behavior of piglets after weaning. Applied Animal Behavior Science 79:221-231.

Einarsson, S. H.; Andersson, K.; Wallgren, M.; Lundström, K. and Rodriguez-Martinez, H. 2009. Short- and long-term effects of immunization against gonadotropin-releasing hormone, using Improvac (TM), on sexual maturity, reproductive organs and sperm morphology in male pigs. Theriogenology 71:302-310.

Fábrega, E.; Velarde, A.; Cros, J.; Gispert, M.; Suarez, P.; Tibau, J. and Soer J. 2010. Effect of vaccination against gonodotropingreleasing hormone, using Improvac ${ }^{\circledR}$, on growth performance, body composition, behavior and acute phase proteins. Livestock Science 132:53-59.

Hintze, S.; Scott, D.; Turner, S.; Meddle, S. L. and D'Eath, R. B. 2013. Mounting behaviour in finishing pigs. Applied Animal Behaviour Science 147:69-80.

Jaros, P.; Bürgi, E.; Stärk, K.D.C.; Noel, R.; Hennessy, D.; Thun, R. 2005. Effect of active immunization against $\mathrm{GnRH}$ on androstenone concentration, growth performance and carcass quality in intact male pigs. Livestock Production Science 92:31-38.

Martin, P. and Bateson, P. 2007. Measuring behavior: an introductory guide. Cambridge University Press, Cambridge.

Martins, P. C.; Albuquerque, M. D.; Machado, I. P. and Mesquita, A. A. 2013. Implicações da imunocastração na nutrição de suínos e nas características de carcaça. Archivos de Zootecnia 62:105-118.

Noguchi, K.; Gel, Y. R.; Brunner, E. and Konietschke, F. 2012. NparLD: an R software package for the nonparametric analysis of longitudinal data in factorial experiments. Journal of Statistical Software 50:1-23.

O’Connell, N. E.; Beattie, V. E. and Moss, B. W. 2004. Influence of replacement rate on the welfare of sows introduced to a large dynamic group. Applied Animal Behavior Science 85:43-56.

Pandorfi, H.; Silva, I. J. O.; Carvalho, J. L. and Piedade, S. M. S. 2006. Estudo do comportamento bioclimático de matrizes suínas alojadas em baias individuais e coletivas, com ênfase no bem-estar animal na fase de gestação. Revista Engenharia Rural 17:1-10.

Prunier, A.; Bonneau, M.; Von Borell, E. A.; Cinotti, S.; Gunn, M.; Fredriksen, B.; Giersing, M.; Morton, D. B.; Tuyttens, F. A. M. and Velarde, A. 2006. A review of the welfare consequences of surgical castration in piglets and evaluation of non-surgical methods. Animal Welfare 15:277-289.

Rostagno, H. S.; Albino, L. F. T.; Donzele, J. L.; Gomes, P. C.; Oliveira, R. F.; Lopes, D. C.; Ferreira, A. S.; Barreto, S. L. T. and Euclides, R. F. 2011. Tabelas brasileiras para aves e suínos: composição de alimentos e exigências nutricionais. Departamento de Zootecnia, Viçosa, MG.

Rydhmer, L.; Zamaratskaia, G.; Adersson, H. K.; Algers, B.; Guillemet, R. and Lundeström, K. 2006. Aggressive and sexual behavior of growing and finishing pigs reared in groups, without castration. Acta Agriculturae Scandinavica Section A-Animal Science 56:109-119.

Rydhmer, L.; Lundström, K. and Andersson, K. 2010. Immunocastration reduces aggressive and sexual behavior in male pigs. Animal 4:965-972.

Studnitz, M.; Jensen, M. B. and Pedersen, L. J. 2007. Why do pigs root and in what will they root? A review on the exploratory behaviour of pigs in relation to environmental enrichment. Applied Animal Behaviour Science 107:183-197.

Thun, R.; Gajewski, Z. and Janett, F. F. 2006. Castration in male pigs: techniques and animal welfare issues. Journal of Physiology and Pharmacology 57:189-194.

Velarde, A.; Gispert, M.; Font-I-Furnols, M.; Dalmau, A.; Soler, J.; Tibau, J. and Fábrega, E. 2008. The effect of immunocastration on the behavior of pigs p.32-33. In: Proceedings of the EAAP Working Group on Production and Utilisation of Meat from Entire Male Pigs. Monells, Spain.

Weiler, U.; Götz, M.; Schmidt, A.; Otto, M. and Müller, S. 2013. Influence of sex and immunocastration on feed intake behavior, skatole and indole concentrations in adipose tissue of pigs. Animal 7:300-308. 